\title{
Tufted angioma in ear auricle: importance of the differential diagnosis
}

\author{
Hemangioma em penacho no pavilhão auricular: \\ importância do diagnóstico diferencial
}

\author{
Carla Andréa Avelar Pires ${ }^{1}$ \\ Gabriela Athayde Amin ${ }^{2}$ \\ Mario Fernando Ribeiro de Miranda ${ }^{4}$
}

\author{
Brena Andrade de Sousa ${ }^{2}$ \\ Maraya de Jesus Semblano Bittencourt ${ }^{3}$ \\ Francisca Regina Oliveira Carneiro ${ }^{5}$
}

DOI: http://dx.doi.org/10.1590/abd1806-4841.20132538

\begin{abstract}
Tufted angioma is an acquired vascular proliferation with specific histological characteristics. The most common clinical features are erythematous macules. It occurs predominantly in children and young adults, especially in the chest and neck. We report the case of a male patient, 12 years old, with an increased right ear auricle associated with erythematous macules and increased local temperature, referred with a diagnosis of lepromatous leprosy; however, this diagnosis was questioned. Histopathology was consistent with tufted angioma. Keywords: Hemangioblastoma; Hemangioma; Vascular malformations
\end{abstract}

Resumo: O Hemangioma em penacho é uma proliferação vascular adquirida de características histológicas peculiares. Sua característica clínica mais comum são máculas eritematosas. Ocorre predominantemente em crianças e adultos jovens, principalmente no tórax e pescoço. Relata-se o caso de paciente do sexo masculino, 12 anos, com aumento do pavilhão auricular direito associado a máculas eritematosas e aumento da temperatura local, encaminhado com diagnóstico de Hanseníase Virchowiana, entretanto, tal diagnóstico foi questionado. Histopatologia compatível com Hemangioma em penacho.

Palavras-chave: Hemangioblastoma; Hemangioma; Malformações vasculares

\section{INTRODUCTION}

The tufted angioma was described for the first time by Wilson Jones as an acquired vascular proliferation of peculiar histological characteristics. Its most common clinical characteristic are erythematous macules and it rarely manifests as plaques or other types of lesions. It occurs predominantly in children and young adults, mainly in the thorax and neck. There are rare associations with pregnancy and liver transplant. Familial cases have already been described. ${ }^{1}$

\section{CASE REPORT}

A 12-year-old male patient, a student from Ananindeua, Pará, looked for medical care, accompanied by his father, due to right ear auricle volume increase that had started 5 years ago. He reported that the increase in volume began associated with a "red" (sic) spot, which progressively expanded causing a large volume increase of the large helix of the right ear, with light local itching, without other symptoms. He denied previous treatments, local traumatism or comorbidities.

Received on 13.02.2013.

Approved by the Advisory Board and accepted for publication on 12.03.2013.

Work carried out at Universidade do Estado do Pará (UEPA) - Belém (PA), Brazil.

Conflict of interest: None

Financial Support: None

MD, dermatologist, Master's degree in Tropical Diseases from Universidade Federal do Pará (UFPA) - Assistant professor of Dermatology at Universidade do Estado do Pará (UEPA) - Belém (PA), Brazil.

MD, Resident dermatologist at Universidade do Estado do Pará (UEPA) - Belém (PA), Brazil.

MD, dermatologist, Master's degree in Tropical Diseases from Universidade Federal do Pará (UFPA) - Assistant professor of Dermatology at Universidade Federal do Pará (UFPA) - Belém (PA), Brazil.

MD, dermatologist, Dermatopathologist. - Assistant professor of Dermatology at the Medical School of Universidade Federal do Pará (UFPA) - Belém (PA), Brazil.

MD, dermatologist, PhD degree in Dermatology from the Universidade Federal de São Paulo (Unifesp) - Associate Professor IV at Universidade do Estado do Pará (UEPA) - Belém (PA), Brazil. 
Considering the epidemiology of the region and the infiltrative aspect of the external ear size increase, as well as a weakly-positive anti-PGL1 test done previously, the patient was referred from another service with a diagnosis of Lepromatous Leprosy, to start polychemotherapy. However, the rate of evolution, the clinical condition and the clinical lesion were not consistent with this diagnosis, so a biopsy of the lesion was done for better clarification.

The dermatological exam showed volume increase of the large helix of the right ear, well-defined erythematous macules with irregular contours, the largest one measuring $07 \times 06 \mathrm{~cm}$; two erythematous papules on the anterior portion of the helix, besides increased local temperature on the right ear large helix and retroauricular region (Figures 1 and 2).

The histopathological exam showed dermis with proliferation of vascular nature, organized in lobes, composed of capillaries, venules and harder endothelial ovoid cell aggregates. The stroma presented a desmoplastic aspect, with scarce focal lymphocytic inflammatory infiltrate. The diagnosis was Hemangioma, variant tufted hemangioma (Figures 3 and 4).

Since it was a benign lesion, expectant management was adopted and no other vascular malformation was evident after imaging exams.

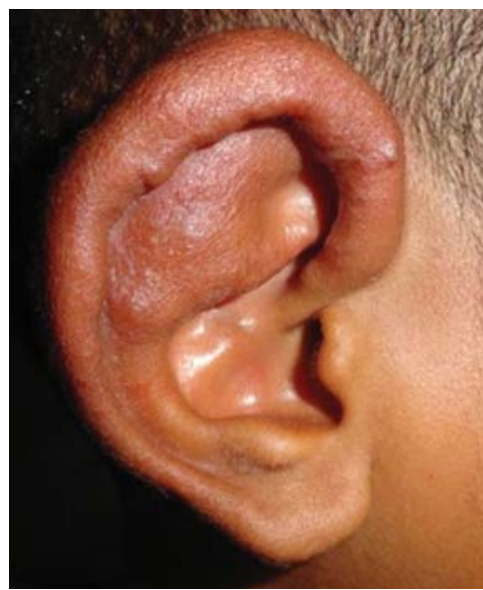

FIGURE 1: Volume increase of the right ear large helix with macules and two erythematous papules on the anterior portion of the helix

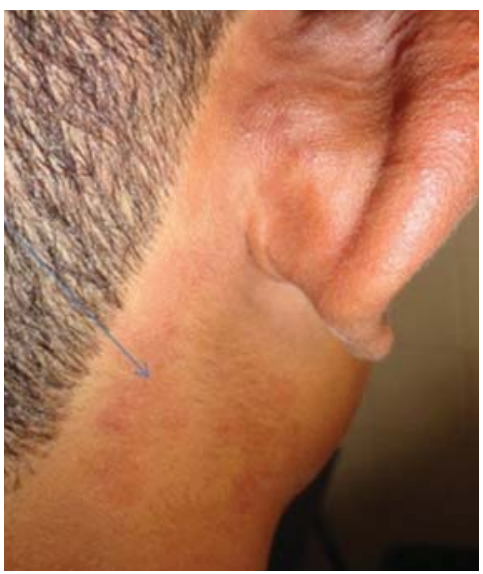

FIGURE 2: Volume increase of the right ear large helix and presence of erythematous macule in the retroauricular area

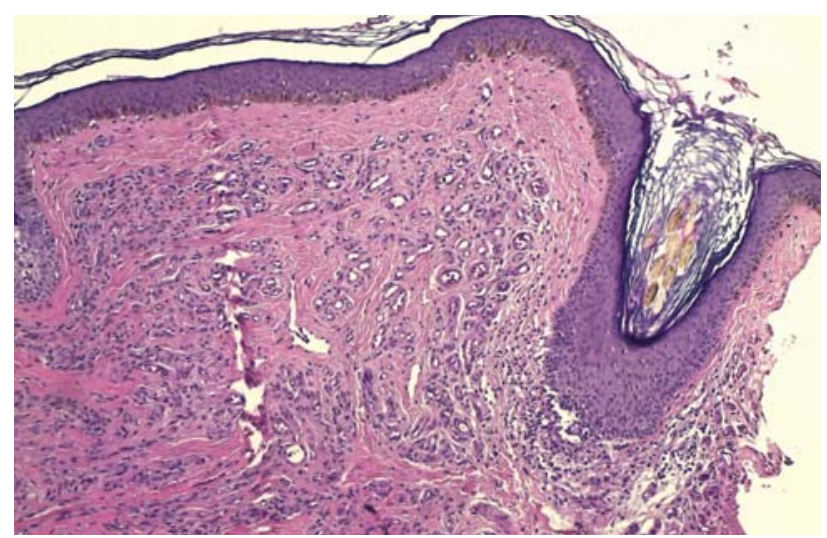

FIGURE 3: Histopathologic exam showing no alterations in the epidermis; dermis showing ectatic capillaries and dense vascular proliferation without atypias associated with low density perivascular lymphocytic inflammatory infiltrate

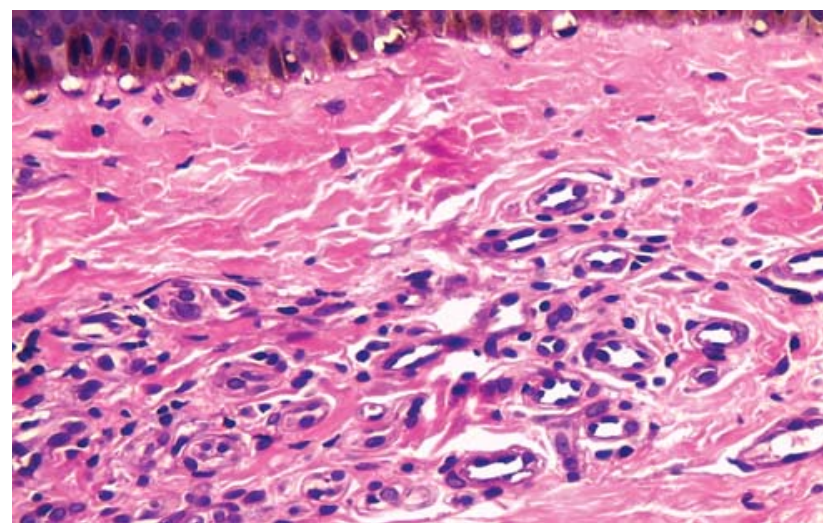

Figure 4: Histopathologic exam, 40x magnification, showing dermis constituted by capillaries, venules and harder ovoid endothelial cell aggregates

\section{DISCUSSION}

The tufted hemangioma, also known as Nakagawa's angioblastoma, is an uncommon benign tumor of varied clinical presentation. The histopathological findings are the key for the diagnosis. ${ }^{2}$ It was described for the first time in 1949, and later, in 1971, by Macmillan and Champion as progressive capillary hemangioma. In 1976, in a ten case series, Jones designated it tufted hemangioma. More than 200 cases have been reported already, the majority in Japan; however, there has never been an association with malignant transformation.

Around $15 \%$ of cases are congenital occurrences, $50 \%$ in the first year of life. The great majority of them appear before 10 years of age, with equal prevalence in both sexes. ${ }^{2,3,4,5}$

Occasionally there may be grave complications, like coagulopathy by sequestration of platelets and coagulation factors by vascular components of the tumor, known as Kasabach-Merritt Syndrome $(\mathrm{KMS}){ }^{2,6,7}$ 
The lesions are represented by macules or plaques with progressive growth that become relatively stable. ${ }^{4}$ It can start as small violaceous papules which expand slowly, and there might be hyperhidrosis and hypertrichosis. ${ }^{8}$ It is usually asymptomatic.

Histopathologically it is composed of ovoid lobes or tufts of angiomatous proliferation, similar to cannon balls, with stenotic lumen, in the dermis; occasionally it may reach the subcutaneous. The morphology of the lobes resembles those found in pyogenic granuloma. Hemosiderin may be detected in the lesion, whereas inflammatory processes and edemas are not usually found. Some authors describe the proliferation of eccrine glands next to the vascular lobes. ${ }^{1,9}$

The treatment options are several and vary according to the manifestation in each patient. Since there is the probability of spontaneous remission, especially in childhood, expectant management is recommended, for monitoring and detection of possible complications like Kasabach-Merritt Syndrome (KMS).,8

The treatment is recommended for lesions that cause organic dysfunction, KMS or intense symptoms. Local compression, systemic corticoids, vincristine, embolization, excision surgery, IFNa, cryosurgery, laser, chemotherapy or radiotherapy may be adopted. $2,7,8,10$

Lesions in the ear auricle are not uncommon. The recognition of angiomatous tumoral lesions in this site is important to avoid inadequate diagnosis and approaches, which usually affect the ear auricle, like lacaziosis, leishmaniasis and leprosy, especially in regions that are endemic for tropical diseases.

\section{REFERENCES}

1. Weedon D. Weedon's Skin Pathology. 3rd ed. Philadelphia: Churchill Livingstone; 2009.

2. Sadeghpour M, Antaya RJ, Lazova R, Ko CJ. Dilated lymphatic vessels in tufted angioma: a potential source of diagnostic confusion. Am J Dermatopathol. 2012;34:400-3.

3. Yaghoobi R, Aliabdi M, Feily A, Ranjbari N, Shahriari S. Reddish-brown plaque on the left buttock. Indian J Dermatol Venereol Leprol. 2012;78:231.

4. Sarma N, Das S, Roy AK. Annular tufted angioma. Indian J Dermatol Venereol Leprol. 2007;73:435-6.

5. Silva RS, Bressan AL, Nascimento LB, Kac BK, Azulay-Abulafia L. Tufted angioma and myofascial pain syndrome. An Bras Dermatol. 2011;86:125-7.

6. Ateyya N, F Botros M, Abdo I, Foda S, Amer H, Saad S. Tufted angioma. Egypt Dermatol Online J. 2005;1:9.

7. Schaffer JV, Fangman W, Bossenbroek NM, Meehan SA, Kamino H. Tufted angioma. Dermatol Online J. 2008;14:2.

8. Reddy IS, Anuradha SV, Swarnalata G. Congenital giant tufted angioma. Indian J Dermatol Venereol Leprol. 2009;75:639.

9. Elder D. Lever's Histopathology of the Skin. 10th. ed. Philadelphia: Lippincott Williams \& Wilkins; 2008.

10. Alberola FT, Betlloch I, Montero LC, Nortes IB, Martínez NL, Paz AM. Congenital tufted angioma: Case report and review of the literature. Dermatol Online J. 2010;16:2.

\author{
MAILING ADDRESS: \\ Brena Andrade de Sousa \\ Travessa Perebebuí, 2623 - Marco \\ 66087-670 - Belém - PA \\ Brazil \\ E-mail: brenasousa@gmail.com
}

How to cite this article: Pires CAA, Sousa BA, Amin GA, Bittencourt MJS, Miranda MFR, Carneiro FRO. Tufted angioma in ear auricle: importance in the differential diagnosis. An Bras Dermatol. 2013;88(6 Suppl 1):S113-5. 